\title{
Occurrence and histopathological effect of Ligula intestinalis on Sea bream (Abramis brama Orientalis)
}

\author{
A Bozorgnia ${ }^{1}$, SH Omidzahir ${ }^{2} *$, S M Hoseini ${ }^{3}$ and SH Darzi ${ }^{1}$ \\ ${ }^{1}$ Faculty of Veterinary Medicine, Islamic Azad University, Ghaemshahr branch, Ghaemshahr, Iran \\ ${ }^{2}$ Faculty of Marine Sciences, University of Mazandaran,Babolsar, Iran \\ ${ }^{3}$ Faculty of Veterinary Medicine, Islamic Azad University, Babol branch, Babol, Iran
}

Received: March 2016

\section{Abstract}

Ligula intestinalis originally is belongs to Cestoda parasite that infests a range of fish family especially Cyprinidae. It is also a zoonosis parasite that affects fish and probably human health. This study tried to isolate $L$. intestinalis from Sea bream (Abramis brama Orientalis), an species classified in family, Cyprinidae, from Caspian Sea. Sixty Sea bream were caught from Caspian Sea, Babolsar Fisheries port. Among that, $26.66 \%$ were infected with $L$. intestinalis. The tissues of infected fishes including gonads, liver and kidney were examined for pathological findings. Ovaries changes showed fibrosis, infiltration of inflammatory cells, atrophy of oocytes; testicular hyperemia, necrosis, fibrosis and degeneration; kidneys necrosis, destruction of tubules, vacuolar degeneration; and liver vacuolar degeneration, biliary duct hyperplasia, necrosis, lymphatic vessel dilatation, fibrosis

Correspondence SH Omidzahir, Faculty of Marine Sciences, University of Mazandaran, Babolsar, Iran (email:sh.omidzahir@umz.ac.ir)
Accepted: May 2016 and cholestasis. Considering the effect of $L$. intestinalis on fish and human health, the prevention programs to disturb the cycle of parasite and more monitoring studies in fish epidemiology especially food fish are recommended.

Keywords:Ligula intestinalis, Abramis brama, Histopathology

\section{Introduction}

L. intestinalis Linnaeus, 1758 is a cestoda from family Pseudophilidae known to be as three-host parasite, infests a range of fish species and find in the forms of free living and farmed fishes all over the world (Geraldine, Jean-Luc\& Sovan 2002; Scholz, Kuchta, Shinn, Snabel\& Hanzelova, 2006). Ligula has a life cycle containing copepods as first, fish as second and piscivorous birds as the final hosts. Parasite eggs are released via bird feces into the water and develop to ciliated coracidium larva. It survives 1-2 days in the water and develops to procercoid larva in copepod. Fish eats the copepod and subsequently, large plerocercoid larva develops 
in the body cavity of fish (Innal, Keskin \& Erk'akan 2007) after eating and digesting by fish. Ligulosis is a food-borne zoonosis and there are several reports of human infestations with this parasite (Urdeş \&Hangan 2013). Sea bream is a species of fish from family Cyprinidae that live in ponds, lakes, canals, slow-flowing rivers and brackish sea waters with muddy bottoms and plenty of algae. It is a food source for human health and has a special ecological and economical importance. Teleost fish especially Cyprinidae are the second intermediate host of $L$. intestinalis and is the most affected because the parasites occupies the body cavity of the fish for several years and is responsible for pathologic effects. Infection occurred by L. intestinalis causes an inflammatory response (Taylor \& Hoole 1995).Severe pathological changes of $L$. intestinalis result from compression for replacement of the organs by the parasites that disturb normal function and histological structures (Abowei \&Ezekie 2011).This article tries to show the effect $L$. intestinalis on occurrence of the histopathological findings in Sea Bream.

\section{Materials and Methods}

\section{Fish Sampling and Parasite Identification}

The station of this study was located in southern east of the Caspian Sea, Babolsar. Sixty Sea bream with average weight of $324 \pm 79.85 \mathrm{~g}$ and total length of $29.4 \pm 3.58 \mathrm{~cm}$ were prepared by seine net (Table 1). After biometry, the fish samples were necropsied and the body cavities examined for the presence of plerocercoids of $L$. intestinalis. The parasite samples were then fixed with $70 \%$ ethanol and identified using biological keys (Bykhovskaya 1964; Gusseve 1985). Length and weight of each parasite isolated from the infected fish was measured (Table 2). The number of infected fish was recorded; the prevalence of parasites and the mean intensity of infection were calculated (Table 2) according the following formula (Bush,Lafferty, Lotz \&Shostak1997)

Prevalence of parasites $(\%)=$ the number of infected fish/ the total number of examined fish $\times 100$

Mean intensity of infection $=$ the number of counted parasites/ the total infected fish

\section{Pathological Examination}

The tissues of infected fishes including gonads (ovary and testis), liver and kidneywere dissected and fixed in $10 \%$ formalin buffer and transferred to the laboratory. The tissue samples were prepared intissue processor (DS2000/H, Iran). Serialsections of formalin-fixed, paraffinembedded of tissue samples were cut using rotary microtome (Leitz, 1512, Germany) at 5 $\mu \mathrm{m}$, then stained by routine hematoxylin and eosin (H\&E)and examined by light microscopy for pathological findings (Bancroft\&Gamble 2007).

\section{Results}

\section{Parasite infection}


The result of this study showed that $26.66 \%$ of total studied fish were infected to $L$. intestinalis (fig.1), of which $81.25 \%$ of them were reported as male and $18.75 \%$ female. The number of non- infected and infected fishes, weight and length of plerocercoid of $L$. intestinalis and the prevalence and mean intensity of infection were listed in Tables 1 and 2.

Table 1 Examined fish, non-infected fish, weight and Length of fishes in present study

\begin{tabular}{cccccc}
\hline Examined fish $(\mathrm{n}=60)$ & Non infected fish & $\begin{array}{c}\text { weight of fish }(\mathrm{gr}) \\
\text { Mean } \pm \text { SD }\end{array}$ & $\begin{array}{c}\text { Length of fish }(\mathrm{cm}) \\
\text { Mean } \pm \text { SD }\end{array}$ \\
\cline { 1 - 3 } female & male & female & male & & \\
\cline { 1 - 4 } 15 & 45 & 12 & 32 & $324 \pm 79.85$ & $29.4 \pm 3.58$ \\
\hline
\end{tabular}

Table 2 Infected fish, Weight and Length of plerocercoid of L. intestinalis, prevalence and mean intensity of infection in present study

\begin{tabular}{|c|c|c|c|c|c|}
\hline \multicolumn{2}{|c|}{ Infected fish } & \multirow{2}{*}{$\begin{array}{l}\text { Weight (gr) } \\
\text { of parasite } \\
\text { Mean } \pm S D\end{array}$} & \multirow{2}{*}{$\begin{array}{l}\text { Length }(\mathrm{cm}) \\
\text { of parasite } \\
\text { Mean } \pm \text { SD }\end{array}$} & \multirow[t]{2}{*}{$\begin{array}{c}\text { Prevalence of } \\
\text { parasite }\end{array}$} & \multirow{2}{*}{$\begin{array}{c}\text { Mean } \\
\text { intensity of } \\
\text { infection }\end{array}$} \\
\hline female & male & & & & \\
\hline 3 & 13 & $132.25 \pm 54.91$ & $60.03 \pm 24.68$ & $26.66 \%$ & 1.75 \\
\hline
\end{tabular}

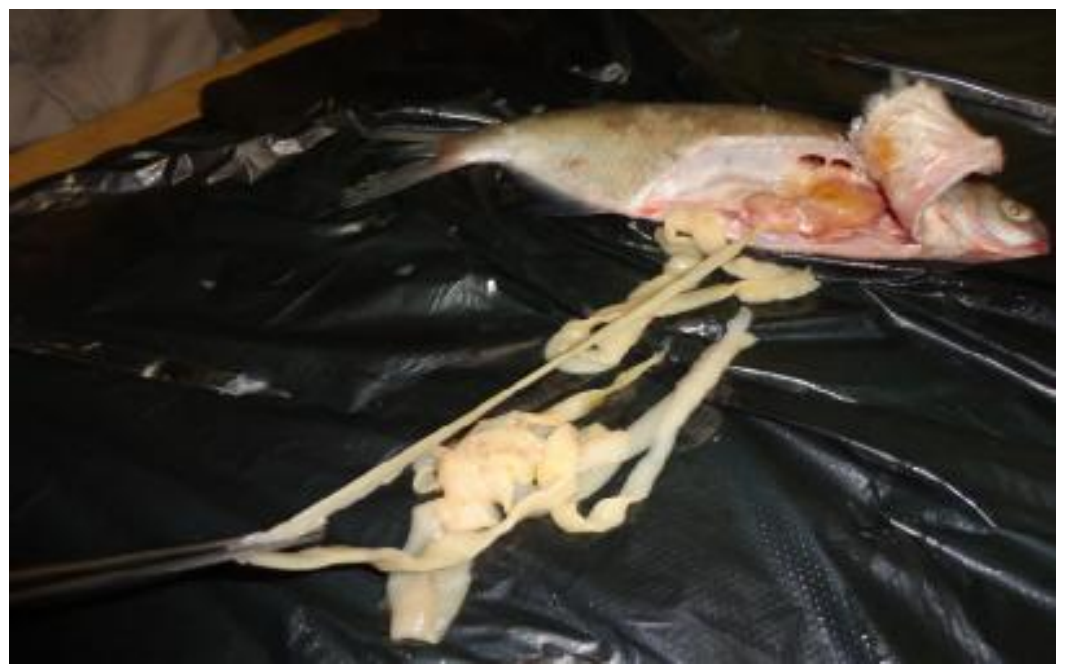

Figure 1 The $L$. intestinalis parasite isolated from A. brama

\section{Pathological finding}

The pathologic finding in ovaries showed fibrosis, infiltration of inflammatory cells, atrophy and destruction of oocytes (Fig.2).In testicular tissues, hyperemia, necrosis, fibrosis and degeneration were observed(Fig.3).In kidneys necrosis, destruction of tubules, vacuolar degeneration, loss of coordination of glomeruli, fibrosis, and infiltration of 


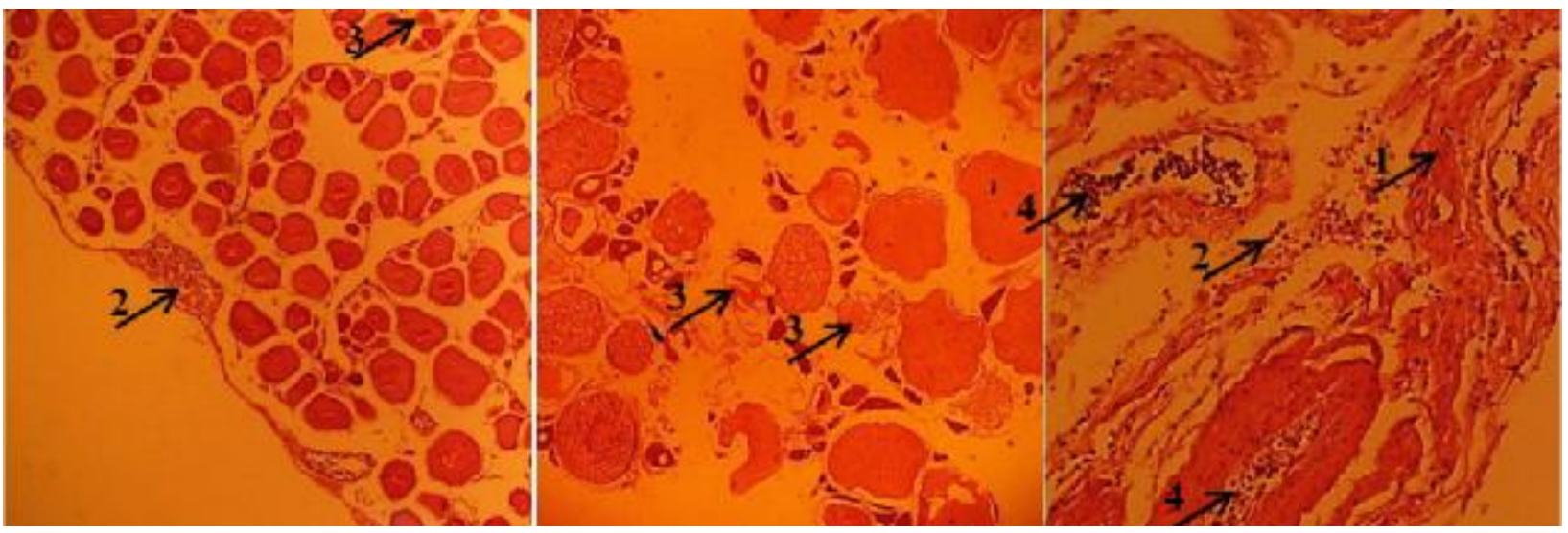

Figure 2 Ovary 1: fibrosis, 2: infiltration of inflammatory cells, 3: atrophy and destruction of oocytes and 4: inflammatory cells in blood vessel, H\&E (10, 40, 40X, respectively from the left side).

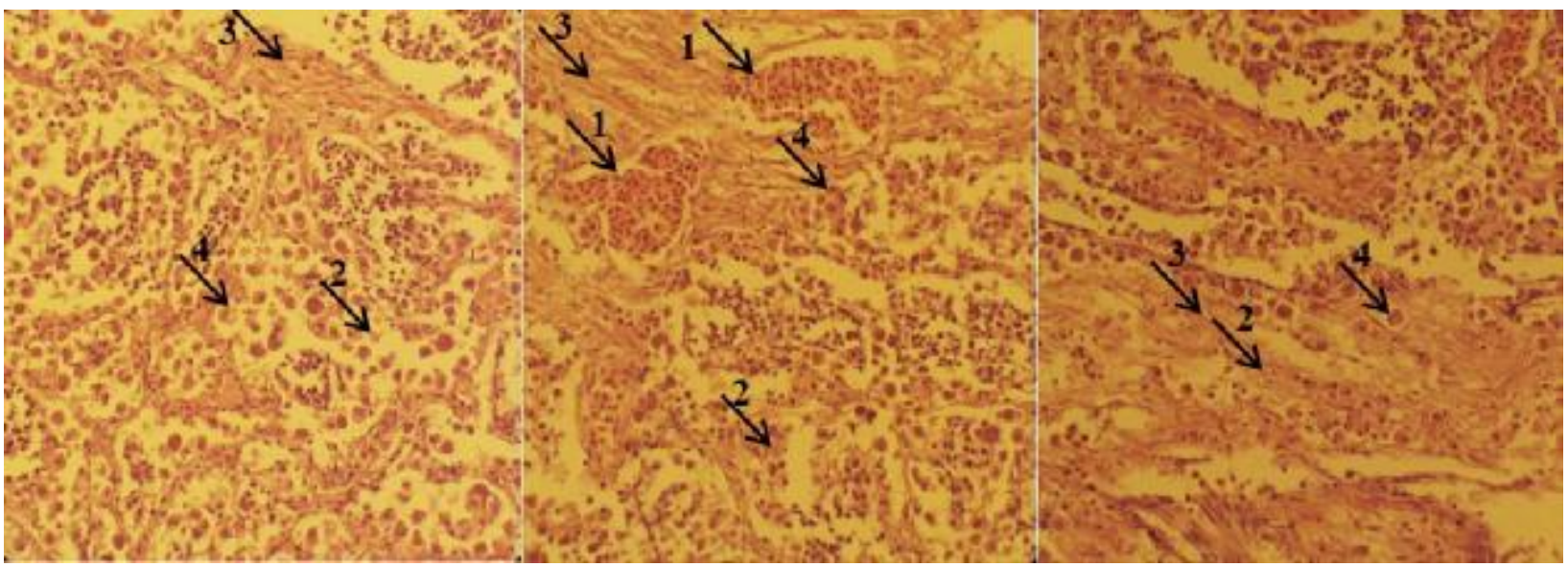

Figure 3 Testicular tissue 1: Hyperemia, 2: Necrosis, 3: Fibrosis and 4: Vacuolar degeneration, H\&E, (40, 40,40X, respectively from the left side).

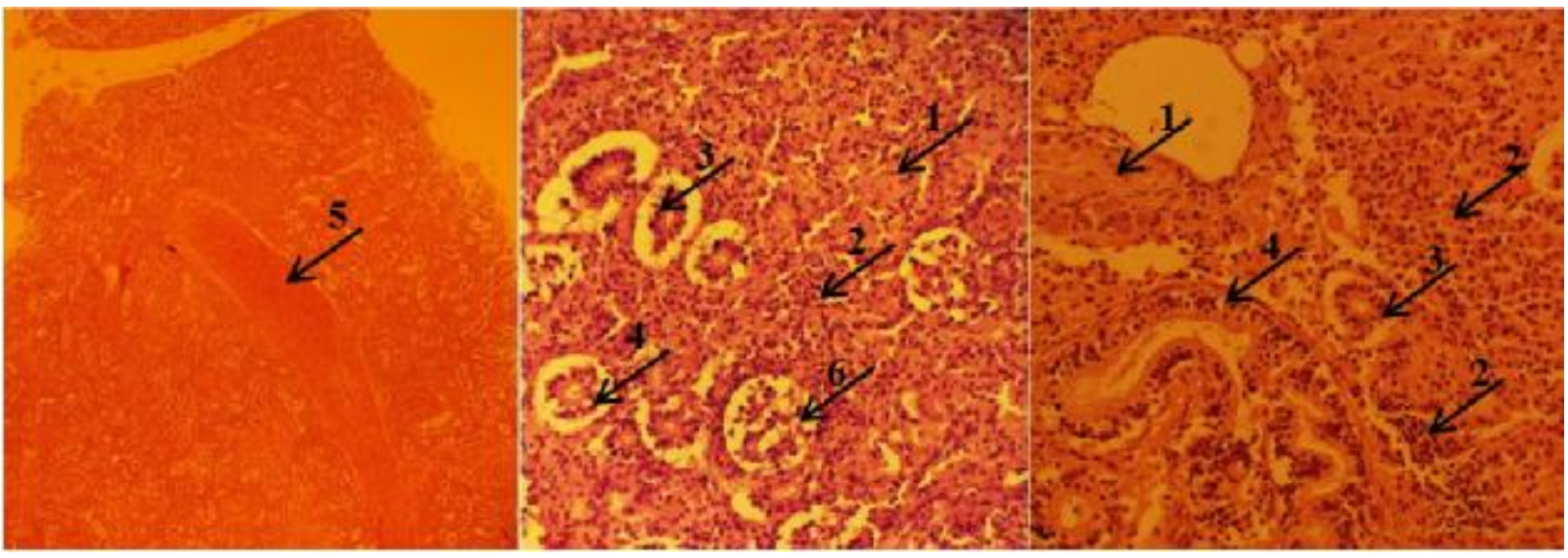

Figure 4 Kidney 1: fibrosis, 2: infiltration of inflammatory cells, 3: necrosis, 4: vacuolar degeneration, 5: hyperemia and 6: loss of coordination of glomeruli, $\mathrm{H} \& \mathrm{E}$ (4, 10, 40X, respectively from the left side). 
inflammatory cells (lymphocyte, plasma cell and macrophage) were seen (Fig.4). In liver pathologic finding showed vacuolar degeneration, infiltration of inflammatory cells, hyperemia, biliary duct hyperplasia, necrosis, cirrhosis, lymphatic vessel dilatation, fibrosis and cholestasis (Fig.5).
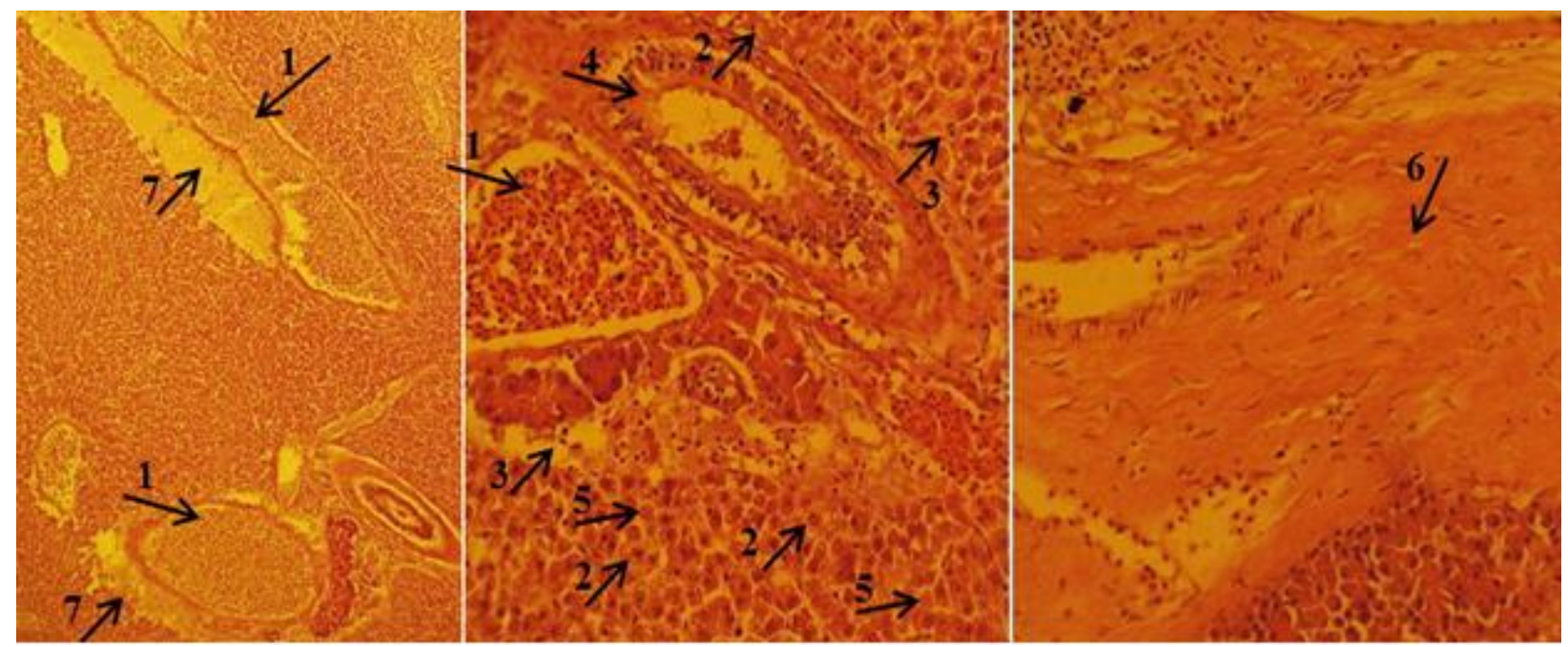

Figure 5 Liver 1: hyperemia, 2: vacuolar degeneration, 3: infiltration of inflammatory cells, 4: biliary duct hyperplasia, 5: necrosis, 6: cirrhosis, 7: exudation. H\&E (10, 40, 40 X, respectively, from the left).

\section{Discussion}

Fish infected to L. intestinalis has been reported in some studies in Iran. Considering the effect of L. intestinalis on fish and human health, continuous study in different fishes especially in food fish is required.Ahmadiara, Hosseini, Jalousian, Ebrahimzadeh Mousavi, Sakhaiifar \& Gerami Sadeghian (2013) reported 16.02\% L. intestinalis infection in Alburnoides bipunctatus and Abramis brama from north and northwest of Iran.Pazouki,Masoumian, Yahyazadeh \& Abbasi(2007) reported L.intestinalis from Sea Bream of Aras dam with prevalence rate of 38.46\%. Jalali and barzegar(2006) reported $L$. intestinalisin Chalcalburnus sp. fromZarivar
Lake withprevalence of $43 \%$.In this study $27 \%$ of a total 60 Sea Breamfrom Caspian Sea were infected to $L$. intestinalis.

Fishes are the second host that affected with the most pathogenic lesions of $L$. intestinalis, because it invases the body cavity of the fish and can be stay there for several years (Barber\&Wright, 2005). The rapid growth of the L. intestinalis in the fish's body cavity shows the first pathological effect, because of swelling of the abdominal region (Taylor \& Hoole 1995; Geraudie, Boulange, Gerbron, Hinfray, Brion\& Minier 2009). The parasite can contain up to $10 \%$ of the host weight, press on the visceral 
organs and the abdominal wall results in loss of fish growth, particularly in juveniles that reduce the ability of ligulosed fish to escape predation (Abowei \& Ezekie 2011). Parasite made pressure to abdominal cavity caused peritonitis and chronic granulomatous hepatitis. Pathologic lesions including tubular fibrosis and necrosis were observed near the hematopoietic tissue or kidney portal. In present study, kidneys showed necrosis, destruction of tubules, vacuolar degeneration, loss of coordination of glomeruli, fibrosis, and infiltration of inflammatory cells and in liver vacuolar degeneration, infiltration of inflammatory cells, hyperemia, biliary duct hyperplasia, necrosis, cirrhosis, lymphatic vessel dilatation, fibrosis and cholestasis. Rahmati holasoo, Hajimohammadi, Ahmadiara, Ebrahimzadeh Mousavi, Rostami-bashman, Haghighi khiabanian asl, Sohrabi Haghdoost, Shokrpoor \& Ghorbanalipour (2011) reported cholangiohepatitis and metaplastic hyperplasia in liver, deformity of structure and function of hepatocytes, thrombosis in liver, decrements in intestine and pancreas as the result of compressive stimulations of $L$. intestinalis in Alburnoides bipunctatus. Ligula infections are also associated with reduction the muscle mass of fish with atrophy the mass of the body wall musculature (Barber\& Wright 2005). Infection by $L$. intestinalis induces pathological lesion such as inflammatory response, atrophy of the viscera specifically, impaired reproduction (Geraudieet al. 2009).
Ligula plerocercoids can inhibit gonadal development of fish hosts' population (Ergonul \&Altindag2005). Inhibition of gonadal maturation result to incompletely immature reproductive tissues (Hecker \& Karbe 2005). L. intestinalis restricts gonadotropin-releasing hormone secretion by interfering with the pituitary-gonadal axis at the level of the host's hypothalamus as result of pressure (MartinSkilton, Lavado, Thibaut, Minier\& Porte 2006). Endocrine disrupting compounds of parasite have been reported to be responsible for impaired gonadal growth, reduced steroid synthesis and inhibition of aromatase activity (Jobling, Beresford, Nolan, Rodgers-Gray, Brighty, Sumpter \& Tyler 2002). Ligulosis prevented gametogenesis and result in noticeable hypopituitarism, poor gonad development, inhibition of gametogenesis of the reproductive cells and impaired spawning behavior (Barber \& Wright 2005). In this study, the ovaries showed fibrosis, infiltration of inflammatory cells, atrophy and destruction of oocytes and in testicular tissues hyperemia, necrosis, fibrosis and degeneration were observed. Parsa Khanghah,Mojazi Amiri, Sharifpour, Jalali Jafari \& Motalebi (2011) reported significant difference between the means of male and female gonads maturation rate in infected and non-infected Chalcalburnus mossulensis. They mentioned infection by L.intestinalis can be the reason for lack of gonads maturation, abnormal degenerative changes like, absorption follicle, hemorrhage and infiltration of inflammation 
cells in ovary tissues of infected fish and in testicle tissue, dispersed hemorrhage, atrophy and melano-macrophage center were reported. Carter,Pierce, Dufour, Arme \& Hoole (2005) indicated that the pituitary glands of roach Rutilus rutilus infected to $L$. intestinalis contained approximately 50\% less luteinizing hormone than non-infected fishes that indicates a significant and measurable effect of parasitism on the pituitary gland. Fibrosis, failure in ovulation, inflammation and presence of melanomacrophages along with infiltration of lymphocytes into parenchyma of ovary indicate atrophy of ovary that is due to exertion of pressure on the tissue and immaturity of ovules (Rahmati-holasoo et al. 2011). The pathological effects mostly involve the inhibition of gonadal development in the fish and may play a role in the regulation of their fish hosts' population (Barber \& Wright 2005).

Considering the results of this study and the other researches on Ligula and because of this parasite infects a range of fish species including fresh water, brackish water, free living and farmed fishes all over the world and also it is a zoonotic parasite, more monitoring studies on fishes are needed and the prevention programs to disturb the cycle of infection.

\section{References}

Abowei J.F.N. \& Ezekie E.N. (2011) Trematoda, Tape Worms: Infections by Larval and Other Tape Worms; and Nematoda in African Fish (A Review). International Journal of Animal and Veterinary Advances 3(5), 352366.

Ahmadiara E., Hosseini S.H., Jalousian F., Ebrahimzadeh Mousavi H.A., Sakhaiifar S., \&Gerami Sadeghian A. (2013) The study of the plerocercoid of diphyllobothriidae (cestoda, pseudophyllidea) in two cyprinid hosts, Abramis brama and Alburnoides bipunctatus from north and northwest of Iran. Iranian Journal of Veterinary Medicine 7(2), 103-10.

Bancroft J.D., Gamble M. (2007) Theory and Practice of HistologicalTechniques $6^{\text {th }} \mathrm{ed}$. Churchill Livingstone.

Barber I. \& Wright H. (2005) Effects of parasites on fish behavior: interactions with host physiology. Behavior and Physiology of Fish24, 122-139.

Bush A.O., Lafferty K.D., Lotz J.M. and Shostak A.W. (1997) Parasitology meets ecology on its own terms: Margolis et al. revisited. Journal of Parasitology 83, 575-583.

Bychowsky B.E. (1949) Monogenetic trematods of some fish of Iran collected by E.N. Pavlowsky. Trudi Zoologicheskovo Instituta Akademiya 8(4), 870-878.

Carter V., Pierce R., Dufour S., Arme C. \& Hoole D. (2005) The tapeworm Ligula intestinalis (Cestoda: Pseudophyllidea) inhibits 
LH expression and puberty in its teleost host, Rutilus rutilus. Reproduction 130, 939-945.

Gusseve A.V. (1983) Methods for collecting and processing of fish parasiticmonogenean materials.Nauka, USSR, Leningrad. (In Russian).

Geraudie P., Boulange L., Gerbron M., Hinfray N., Brion F. \& Minier C. (2009) Endocrine effects of the tapeworm Ligula intestinalis in its teleost host, the roach (Rutilus rutilus). Parasitology136, 1-8.

Geraldine loot, Jean-Luc Giraudel, Sovan lek (2002) A non-destructive morphometric technique to predict Ligulae intestinalis plerocercoid load in roach (Rutilus rutilus L.) abdominal cavity. Ecological Modeling Journal 156(115):1-11.

Innal D., Keskin N., Erk'akan F. (2007) Distribution of Ligula intestinalis in Turkey.Turkish Journal of Fisheries and Aquatic Sciences 7, 19-22.

JalaliB. \& Barzegar M. (2006) Fish Parasites in Zarivar Lake. Journal of Agriculture Science and Technology 8, 47-58.

Jobling S., Beresford N., Nolan M., RodgersGray T., Brighty G.C., Sumpter J.P. \& Tyler C.R. (2002) Altered sexual maturation and gamete production in wild roach (Rutilus rutilus) living in rivers that receive treated sewage effluents. Biology of Reproduction 66, 272-228.

Martin-Skilton R., Lavado R., Thibaut R., Minier C. \& Porte C. (2006) First evidence of endocrine disruption in red mullets (Mullus barbatus) from the NW Mediterranean Sea. Environmental Pollution 141, 60-68.

Parsa Khanghah A., Mojazi Amiri B., Sharifpour I., Jalali Jafari B.\& Motalebi A. (2011) Gonads tissue changes of Chalcalburnus mossulensis(Heckel, 1843) infected by Ligula intestinalis (cestoda). Iranian Journal of Fisheries Sciences10 (1), 85-94.

Pazouki J., Masoumian M., Yahyazadeh M. \& Abbasi, J. (2007) Metazoan parasites from freshwater fishes of northwest. Iranian Journal Agriculture Science and Technology, 25-30.

Rahmati-holasoo H., Hajimohammadi B., Ahmadiara E., Ebrahimzadeh Mousavi H.A., Rostami-bashman M., Haghighi khiabanian asl A., Sohrabi Haghdoost I., Shokrpoor S.\& Ghorbanalipour A. (2011) A study of infestation of Alburnoides bipunctatus with Ligula intestinalis in Latian reservoir Dam Lake, Tehran province, Iran: A histopathological study. Human \& Veterinary Medicine International Journal of the Bioflux Society, 3(1) $18-24$. 
Scholz T., Kuchta R., Shinn A. P., Snabel V. and Hanzelova V. (2006) Host Specificity and geographical distribution of Eupatorium in European salmonid Fish. Journal of Helminthology 77, 225-62.

Taylor M. J.\& Hoole D. (1995) The chemiluminescence of cyprinid leucocytes in response to zymosan and extracts of Ligula intestinalis (Cestoda). Fish and Shellfish Immunology 5, 191-198.

Urdeş L.\& Hangan M. (2013) The Epidemiology of Ligula intestinalis (Phylum Platyhelminthes) within the Cyprinid Populations Inhabitingthe Danubian Delta Area.Animal Science and Biotechnologies 46 (1), 273-276. 


\title{
بر برسى وقوع و اثرات آسيب شناسى ليخولا اينستيناليس | Ligula intestinalis
} Abramis brama orientalis Berg, داهي سيم Linnaeus, 1758

\author{
عباس بزركنيا'، شيلا اميدظهير 2 ، سيد محمد حسينى 3 شهروز درزى1 1 \\ 1 · · دانشكده داميزشكى دانشگاه آزاد اسلامى واحد قائمشهر، قائمشهر، ايران

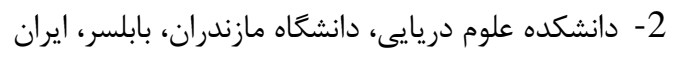

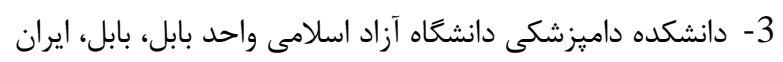

\section{جكيده}

ليكولا اينستيناليس Ligula intestinalis يك انكل سستد است كه طيف وسيعى از ماهىها به ويزه خانواده كيورماهيان را دركير مى كند همجنين يك انكَل زئونوز است كه مى تواند سلامت انسانها را نيز تحت تاثير قرار دهد اين مطالعه سعى داشته است انكل ليكولا اينستيناليس را در ماهى سيم دريايى Abramis brama كه يكى از ماهى هاى خانواده كيورماهيان است مورد

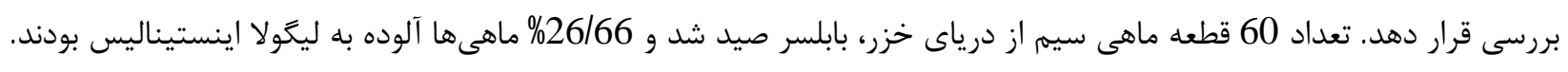

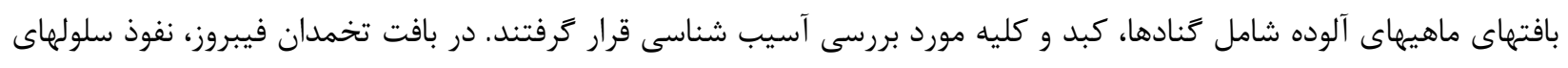
آماسى و آتروفى اووسيتها، در بافت بيضه يرخونى، نكروز، فيبروز و دزنراسيون، در بافت كليه نكروز، تخريب توبولها و دزنراسيون

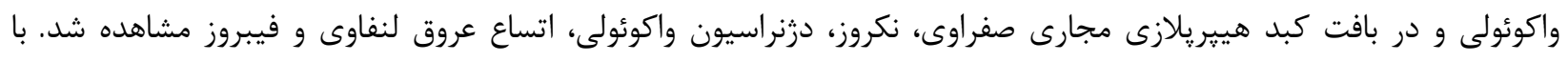

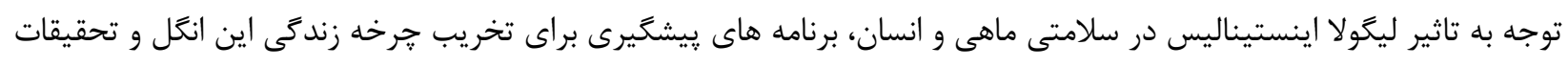

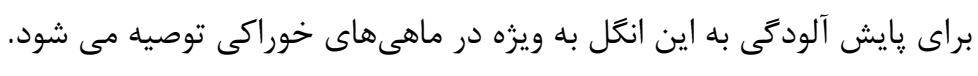
كلمات كليدى ليكولا اينستيناليس، ماهى سيم، آسيب شناسى، sh.omidzahir@umz.ac.ir :نويسنده مسئول: 